\title{
SEISMIC WAVES FROM ATOMIC BOMB TESTS
}

\author{
B. Gutenberg and C. F. Richter \\ (Contribution no. 395, Balch Graduate School of the Geological Sciences, \\ California Institute of Technology)
}

Registration of seismic waves from atomic bombs provides a direct check on accepted traveltime curves. The Baker Day test at Bikint on July 24, 1946, U. T., was recorded at eight stations by short-period Benioff vertical-component seismometers. Only longitudinal waves (P) appear; no transverse waves or surface waves have been found. Figure 1 shows the seismogram at Mount Wilson; the others are similar.

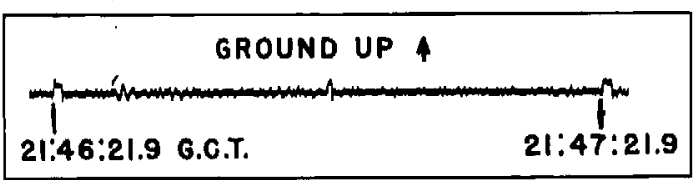

Fig. 1--Bikinl atomic bomb test, July 24, 1946 (U. T.), Mount Wilson short-period vertical component Benioff selsmogram. Original length of minute $60 \mathrm{~mm}$
We are Indebted to the United States Coast and Geodetic Survey for a copy of the Tucson selsmogram and to D. S. Carder of the Coast and Geodetic Survey for coples of those at Boulder City, Pierce Ferry, and Shasta Dam.

The Office of Naval Research has kindly furnished the following data: Time of detonation, $21^{\mathrm{h}} 34^{\mathrm{m}} 59.76 \pm 0.1 \mathrm{sec}$, July 24 (U. T.); position, $11^{\circ} 35^{\prime} \mathrm{N}, 165^{\circ} 30^{\prime} \mathrm{E}$. Results are shown in Table 1.

Table 1--Results of atomic bomb tests

\begin{tabular}{l|ccccc}
\hline \multicolumn{1}{c|}{ Station } & Distance & Time of P & Travel time & o - C \\
\hline & 0 & h m s & m s & sec \\
Shasta Dam & 69.0 & 214607.5 & 1108 & -4 \\
Tinemaha & 72.2 & 214628 & 1128 & -3 \\
Mount Wilson & 72.4 & 214628 & 1128 & -4 \\
Riverside & 73.0 & 214631 & 1131 & -4 \\
Palomar & 73.5 & 214635 & 1135 & -3 \\
Boulder City & 75.0 & 214642 & 1142 & -4 \\
Pierce Ferry & 75.6 & 214647 & 1147 & -3 \\
Tucson & 78.6 & 214704.5 & 1205 & -3 \\
\hline
\end{tabular}

In the column $\mathrm{O}-\mathrm{C}$ are residuals obtained by subtracting from the observed travel times those calculated for a surface focus [see "References" at end of paper, GUTENBERG and RICHTER, 1939, p. 97]. These residuals are probably mainly due to the exceptional structure of the Paclfic basin. The travel times referred to assume origin in a continental region. Supposing continental rocks to be absent in the Pacific basin, rough calculation Indicates that travel times to large distances should be about two seconds less. Accordingly, the zero of the standard travel time curve is probably correct within a second or two. This confirms the result for the New Mexico test of 1945 [GUTENBERG, 1946], where the origin time had to be calculated from the arrival of the direct wave $\bar{P}$ at Tucson, and where the observed arrival of $P_{n}$ at Tucson, Palomar, and Riverside was about one second later than expected. Recorded amplitudes of $P$ from the Bikini test are about equal to those of a shock of magnitude 5.5 at the same distance.

\section{References}

GUTENBERG, B., Interpretation of records obtained from the New Mexico atomic bomb test, July 16, 1945, Bull. Seis. Soc. Amer. (forthcoming), 1946.

GUTENBERG, B., and RICHTER, C. F., On seismic waves (fourth paper), Gerlands Beitr. z, Geophys,, v. 54, pp. 94-136, 1939.

California Institude of Technology, Pasadena, Calif.

(Communicated manuscript received September 9, 1946; open for formal discussion until May 1, 1947.) 